\title{
Biology of Bemisia tabaci (Genn.) B biotype (Hemiptera, Aleyrodidae) on tomato genotypes
}

\author{
Maria Auxiliadora de Godoy Oriani ${ }^{1}$; José Djair Vendramim²*; Cristina Jensen \\ Vasconcelos ${ }^{3}$ \\ ${ }^{1}$ USP/ESALQ - Programa de Pós-Graduação em Entomologia. \\ ${ }^{2}$ USP/ESALQ - Depto. Entomologia e Acarologia, C.P. 09 - 13418-900 - Piracicaba, SP - Brasil. \\ ${ }^{3}$ UNIMEP - Graduação em Ciências Biológicas, Rod. do Açúcar, km 156 - 13400-911 - Piracicaba, SP - Brasil. \\ *Corresponding author <jdvendra@esalq.usp.br>
}

\begin{abstract}
Brazil is one of the main tomato (Solanum lycopersicum) producers worldwide. Nevertheless, considerable part of the production is lost due to Bemisia tabaci (Genn.) B biotype attacks. Resistant plants can be an important method for controlling this pest in an integrated pest management. Tests for evaluating some biological aspects of $B$. tabaci were carried out on 18 tomato genotypes, in controlled laboratory greenhouse conditions. Thirty-day-old plants placed in plastic cages were infested with 20 whitefly pairs each, for $24 \mathrm{~h}$. The development of at least 30 eggs in three leaflets per plant (repetition) was observed until adult emergence. The development period of insects grown in LA1335, PI365928 and LA722 genotypes took three days longer when compared to the ones grown in PI134418 (20.3 days). The highest mortality rate of whitefly nymphs occurred in PI365928, LA1335 and LA722 genotypes (63.8, 54.5 and 53.3\%, respectively), and the smallest ones in IAC294 and IAC68F-22-2 genotypes (4.9 e 6.2\%, respectively). LA1335, PI365928 and LA722 genotypes presented moderate feeding nonpreference and/or antibiosis-based resistance to $B$. tabaci B biotype.
\end{abstract}

Key words: insecta, whitefly, antibiosis, antixenosis

\section{Biologia de Bemisia tabaci (Genn.) Biótipo B (Hemiptera, Aleyrodidae) em genótipos de tomateiro}

\begin{abstract}
RESUMO: O Brasil é um dos maiores produtores mundiais de tomate (Solanum lycopersicum), porém grande parte da produção é perdida devido ao ataque de Bemisia tabaci (Genn.) biótipo B. Entre as táticas de controle dessa praga num manejo integrado de pragas, pode-se relacionar a resistência de plantas. Ensaios para avaliar alguns aspectos biológicos de $B$. tabaci foram realizados com 18 genótipos de tomateiro, em condições controladas de laboratório (casa de vegetação). Plantas com 30 dias de idade foram colocadas em gaiolas plásticas e infestadas com 20 casais de moscas-brancas cada, durante 24h. Acompanhou-se então o desenvolvimento de pelo menos 30 ovos em três folíolos por planta (repetição) até a emergência dos insetos. Os insetos criados nos genótipos LA1335, PI365928 e LA722 apresentaram prolongamento de três dias no período de desenvolvimento, em relação aos criados em PI134418 (20,3 dias). As maiores taxas de mortalidade das ninfas de mosca-branca ocorreram nos genótipos PI365928, LA1335 e LA722 (63,8, 54,5 e 53,3\%, respectivamente) e as menores, nos genótipos IAC294 e IAC68F-22-2 (4,9 e 6,2\%, respectivamente). Os genótipos LA1335, PI365928 e LA722 apresentam resistência moderada do tipo não-preferência para alimentação e/ou antibiose a $B$. tabaci biótipo B. Palavras-chave: Insecta, mosca-branca, antibiose, antixenose
\end{abstract}

\section{Introduction}

Brazil produced around 3.35 million tons of tomato (Solanum lycopersicum) (= Lycopersicon esculentum Mill) (Peralta et al., 2006) in 2007, being considered at that time, one of the major producers of this product worldwide (Agrianual, 2009). Nearly 28\% of the production is used in the industry, and $72 \%$ in natura consumption. Nowadays, the whitefly Bemisia tabaci (Genn.) B biotype is one of the main pests both for industrial processing and for fresh tomato. In addition to direct damages caused by extracting large quantities of phloem sap, it also transmits plant viruses (Villas Bôas, 2005). This is the main limiting factor for tomato crop in many producing regions (Markham et al., 1994; Amari et al., 2008; García-Cano et al., 2008), interfering in the tomato pro- duction chain, which holds great economical and social importance in Brazil (EMBRAPA/CNPH, 2006). Losses due to virus transmission range from 40 to $70 \%$, if the plants are infected within 5-6 weeks after germination (Villas Bôas, 2005).

The improvement of germplasm aiming to the development of resistant genotypes to Bemisia spp. may be an important tool in integrated pest management of whitefly (McAuslane et al., 1996), thus preventing unnecessary use of insecticides, which are still widely used in pest control. Nowadays, the cloned Mi-1 gene is one of the most important tomato resistant genes as it confers resistant to $\mathrm{B}$ and Q biotypes of B. tabaci and also to nematodes (Meloidogyne spp.) and potato aphid [Macrosiphum euphorbiae (Thomas)] (De Ilarduya et al., 2004; Jiang et al., 2001; Muñiz and Nombela, 2001; Nombela et al., 2000, 2001, 2003). 
Several authors have observed that the tomato genotypes, LA716 (S. pennellii $=$ L. pennellii), PI134417 and PI134418 (S. habrochaites f. glabratum $=$ L. hirsutum $\mathrm{f}$. glabratum) showed certain resistance to B. tabaci B biotype (Heinz and Zalom, 1995; Fancelli and Vendramim, 2002; Toscano et al., 2002; Muigai et al., 2003; Fancelli et al., 2003, 2005; Baldin et al., 2005). This resistance was associated to the presence of glandular trichomes that release exudates, type IV in S. pennellii (Nombela et al., 2000), and types IV and VI in S. habrochaites f. glabratum (Williams et al., 1980; Channarayappa et al., 1992). Low levels of feeding nonpreference and/or antibiosis were observed in PI127826, PI134417, PI134418 and LA444-1, which lengthened the cycle of the insect when compared with PI126931 (Baldin et al., 2005).

Therefore, this research aimed to evaluate some biological aspects of $B$. tabaci $\mathrm{B}$ biotype on 18 tomato genotypes.

\section{Material and Methods}

Eighteen tomato genotypes were evaluated: Santa Clara, Fanny (S. lycopersicum); VFNA (S. lycopersicum cerasiforme); LA716 (S. pennellii $=$ L. pennellii); LA1963 (S. chilense $=$ L. chilense); LA371, LA444-1, LA462 (S. peruvianum $=$ L. peruvianum); IAC237, LA722, LA1335, NAV1062, PI126931, PI365928 (S. pimpinellifolium $=L$. pimpinellifolium); PI134417, PI134418 (S. habrochaites $\mathrm{f}$. glabratum $=$ L. birsutum f. glabratum); IAC294 (S. habrochaites); IAC68F-22-2 (S. peruvianum $\times S$. lycopersicum). The experiments were carried out in laboratory under the following conditions: $23 \pm 2^{\circ} \mathrm{C}$ temperature, $70 \pm 10 \%$ relative humidity and L13:D11h (Light:Dark) photoperiod.

The seeds of tomato genotypes were germinated in plastic trays containing a substrate composed of vermiculite, perlite, pinus bark and peat. Fifteen days after the sowing, the seedlings were transplanted into $0.5 \mathrm{~L}$ plastic pots containing Plantmax Hortaliças ${ }^{\circledR}$ substrate (one seedling per pot), irrigated with nutritive solution $\left[1 \mathrm{M} \mathrm{KNO}_{3}=5 \mathrm{~mL} \mathrm{~L}^{-1} ; 1 \mathrm{M} \mathrm{KH}_{2} \mathrm{PO}_{4}=1 \mathrm{~mL} \mathrm{~L}^{-1} ; 1 \mathrm{M}\right.$ $\mathrm{MgSO}_{4}=2 \mathrm{~mL} \mathrm{~L}{ }^{-1}$; FeEDTA $=1 \mathrm{~mL} \mathrm{~L}{ }^{-1}$; micronutrients $\left(\mathrm{H}_{3} \mathrm{BO}_{3}, \mathrm{MnCl}_{2} \times 4 \mathrm{H}_{2} \mathrm{O}, \mathrm{ZnCl}_{2}, \mathrm{CuCl}_{2}\right.$ and $\left.\left.\mathrm{H}_{2} \mathrm{MoO}_{4} \times \mathrm{H}_{2} \mathrm{O}\right)=1 \mathrm{~mL} \mathrm{~L}^{-1} ; 1 \mathrm{M} \mathrm{Ca}\left(\mathrm{NO}_{3}\right)_{2}=5 \mathrm{~mL} \mathrm{~L}^{-1}\right]$ (Sarruge, 1975) and maintained in greenhouse.

For whitefly rearing, a colony was initiated from a population previously characterized as B. tabaci (B biotype). The insects were reared on soybean [Glycine max (L.) Merrill] and painted spurge (Euphorbia heterophylla L.) plants kept in a greenhouse with anti-aphid screens.

For plant infestation, a transparent plastic cage (16 $\mathrm{cm}$ height and $13 \mathrm{~cm}$ diameter) was used. The cage had a plastic lid with a $6 \mathrm{~cm}$ diameter hole covered with an anti-aphid screen to facilitate the ventilation of the cage. Experimental insects were introduced into the cage through a hole on the side of the cage. The cages were placed in plastic pots containing 1-month-old tomato seedlings and held in place with the aid of a masking tape $4 \mathrm{~cm}$ width. Each plant was infested by 20 whitefly pairs during 24 h, except LA716, PI134417 and PI134418 genotypes, for which 40 pairs were used during $72 \mathrm{~h}$, in order to reach enough eggs to perform the experiment. Then, the adults were removed and the number of eggs found in the abaxial surface of three leaflets per plant was registered, containing at least 30 eggs in each.

The development of the immatures was observed until adult emergence, and the following parameters were evaluated: number of eggs, ecloded nymphs and emerged adults, in addition to the eggs viability and nymphs mortality. During the experiment, plants were kept in chambers growth of multi-tiered shelving without sidewall and with individual lighting control and irrigated with nutritional solution when needed.

The trials were set up in a randomized block design with six repetitions for each tomato genotype evaluated. The data obtained were first analyzed through the test of homocedasticity by Bartlett, which were transformed accordingly, and then the data were submitted to analysis of variance by the F-test and the means were compared by Tukey test $(p \leq 0.05)$.

\section{Results and Discussion}

The viabilities of the eggs were not different (Table 1). In tomato, high percentages (approximately 99\%) of ecloded whitefly nymphs have also been verified by Hendi et al. (1985) in controlled conditions of temperature and humidity $\left(30 \pm 2^{\circ} \mathrm{C}\right.$ and $\left.60 \pm 5 \%\right)$. In mung beans (Phaseolus radiatus L.), Verma et al. (1990) observed that this parameter ranged from $84 \%$ at $23^{\circ} \mathrm{C}$ to $92 \%$ at $27^{\circ} \mathrm{C}$ and Butler Jr. et al. (1983) reported that the lowest percentages of ecloded nymphs of B. tabaci were from $68 \%$ at $26.7^{\circ} \mathrm{C}$ to $75 \%$ at $32.2^{\circ} \mathrm{C}$, in cotton plants (Gossypium birsutum L.). Also, Wagner (1995) suggested that there was a decreasing tolerance of eggs when high temperatures were reached at the hottest times of the year.

The total development period was longer for insects reared on LA1335 (23.5 days), PI365928 and LA722 (23.4 days) genotypes, when compared with values recorded on PI134418, LA462, IAC68F-22-2, PI134417, LA1963, NAV1062, IAC294, LA371, LA444-1 and LA716, which ranged from 20.3 to 21.1 days. However, the genotype that presented the longest whitefly development period (LA1335) did not differ from PI126931, IAC237, 'Fanny' and 'Santa Clara'. The immature mortality rate was higher for insects raised on PI365928 (63.8\%), LA1335 (54.5\%) and LA722 (53.3\%) and differed of the ones found on IAC294 (4.9\%) and IAC68F-22-2 (6.2\%), which presented the lowest nymphs mortality rates (Table 1 ).

Nombela et al. (2000) and Heinz and Zalom (1995) reported no oviposition on LA716 genotype, and others authors have excluded LA716 from the feeding nonpreference and/or antibiosis test, once the number of eggs required for the study of the whitefly biology was not reached, requisite for the performance of the experiment (Fancelli and Vendramim, 2002; Baldin et al., 2005). Such problem has also been noted in this test for LA716, PI134417 and PI134418 genotypes. Consequently, 
Table 1 - Number of eggs and nymphs ( $n$ ), eggs viability, development period and nymphs mortality of Bemisia tabaci B biotype $( \pm \mathrm{SE})$ on 18 tomato genotypes. Temp.: $23 \pm 2^{\circ} \mathrm{C}, \mathrm{RH}: 70 \pm 10 \%$, photophase: $13 \mathrm{~h}$.

\begin{tabular}{|c|c|c|c|c|c|}
\hline \multirow{2}{*}{ Genotype } & \multicolumn{2}{|c|}{ Eggs } & \multicolumn{2}{|c|}{ Nymphs } & \multirow{2}{*}{ Development period } \\
\hline & $\mathrm{n}$ & Viability & $\mathrm{n}$ & Mortality $^{1}$ & \\
\hline & & $\%$ & & $\%$ & days \\
\hline LA1335 & 399 & $93.7 \pm 2.5$ & 389 & $54.5 \pm 8.4 \mathrm{a}$ & $23.5 \pm 0.5 a$ \\
\hline PI365928 & 407 & $90.0 \pm 6.3$ & 360 & $63.8 \pm 15.4 \mathrm{a}$ & $23.4 \pm 0.6 \mathrm{ab}$ \\
\hline LA722 & 327 & $86.5 \pm 7.3$ & 293 & $53.3 \pm 6.6 \mathrm{ab}$ & $23.4 \pm 0.3 \mathrm{ab}$ \\
\hline PI126931 & 288 & $88.5 \pm 4.9$ & 252 & $38.6 \pm 14.2 \mathrm{abc}$ & $22.7 \pm 0.5 \mathrm{abc}$ \\
\hline IAC237 & 268 & $89.4 \pm 4.5$ & 239 & $29.7 \pm 3.2 \mathrm{abc}$ & $22.3 \pm 0.3 \mathrm{abcd}$ \\
\hline Fanny & 431 & $97.4 \pm 1.7$ & 422 & $25.0 \pm 7.4 \mathrm{abc}$ & $22.2 \pm 0.4 \mathrm{abcd}$ \\
\hline Santa Clara & 431 & $95.5 \pm 1.4$ & 419 & $30.7 \pm 10.31 \mathrm{abc}$ & $22.2 \pm 0.3 \mathrm{abcd}$ \\
\hline VFNA & 329 & $97.2 \pm 2.8$ & 324 & $27.1 \pm 10.6 \mathrm{abc}$ & $21.5 \pm 0.6 \mathrm{bcd}$ \\
\hline LA716 & 642 & $94.1 \pm 3.0$ & 575 & $31.0 \pm 11.1 \mathrm{abc}$ & $21.1 \pm 0.8 \mathrm{~cd}$ \\
\hline LA444-1 & 476 & $95.1 \pm 1.2$ & 445 & $32.3 \pm 11.1 \mathrm{abc}$ & $21.1 \pm 0.3 \mathrm{~cd}$ \\
\hline LA371 & 361 & $97.3 \pm 2.0$ & 345 & $13.7 \pm 5.3 \mathrm{abc}$ & $21.0 \pm 0.5 \mathrm{~cd}$ \\
\hline IAC294 & 428 & $98.8 \pm 0.9$ & 425 & $4.9 \pm 2.3 \mathrm{c}$ & $21.0 \pm 0.3 \mathrm{~cd}$ \\
\hline NAV1062 & 340 & $89.7 \pm 4.8$ & 323 & $20.2 \pm 13.5 a b c$ & $20.9 \pm 0.9 \mathrm{~cd}$ \\
\hline LA1963 & 541 & $98.4 \pm 1.0$ & 532 & $32.0 \pm 7.8 \mathrm{abc}$ & $20.9 \pm 0.5 \mathrm{~cd}$ \\
\hline PI134417 & 221 & $96.2 \pm 1.5$ & 210 & $15.6 \pm 5.6 \mathrm{abc}$ & $20.9 \pm 0.3 \mathrm{~cd}$ \\
\hline IAC68F-22-2 & 532 & $99.1 \pm 0.6$ & 527 & $6.2 \pm 2.6 b c$ & $20.9 \pm 0.2 \mathrm{~cd}$ \\
\hline LA462 & 432 & $97.4 \pm 1.5$ & 427 & $19.0 \pm 6.3 \mathrm{abc}$ & $20.4 \pm 0.3 \mathrm{~d}$ \\
\hline PI134418 & 367 & $92.5 \pm 3.3$ & 341 & $15.7 \pm 5.3 \mathrm{abc}$ & $20.3 \pm 0.3 \mathrm{~d}$ \\
\hline $\mathrm{F}$ & & $1.43^{\mathrm{NS}}$ & & $2.71 *$ & $7.36 *$ \\
\hline $\mathrm{CV} \%$ & & 8.55 & & 54.59 & 4.33 \\
\hline
\end{tabular}

Means followed by the same letters within columns are not different (Tukey's test, $p \leq 0.05) .{ }^{1}$ Original data; transformed in arcsin $(\mathrm{x} / 100)^{1 / 2}$ for analysis.

we decided to leave the females confined for a longer period of time, three days on LA716 and two days on PI134417 and PI134418. Also we duplicated the number of infesting insects (40 pairs), in order to provide enough number of eggs to make possible the inclusion of these genotypes in this experiment. However, the LA716 genotype (S. pennellii) showed susceptibility in the feeding nonpreference and/or antibiosis test, once B. tabaci $\mathrm{B}$ biotype presented a short development (21.1 days) and a lower nymphs mortality rate (31\%) (Table 1). Such fact has also been verified for PI134417 and PI134418 genotypes (S. habrochaites f. glabratum), on which the whiteflies presented short development periods (20.9 and 20.3 days, respectively) and low nymphs mortality (15.6 and $15.7 \%$, respectively) (Table 1 ).

Since LA716, PI134417 and PI134418 presented high oviposition nonpreference resistance in relation to $B$. tabaci B biotype (Heinz and Zalom, 1995; Fancelli and Vendramim, 2002; Toscano et al., 2002; Muigai et al., 2003; Fancelli et al., 2003, 2005; Baldin et al., 2005), these genotypes would not have to spend extra energy in a second type of resistance: the feeding nonpreference and/ or antibiosis. Many times, the whitefly is inhibited to oviposite on LA716 genotype, and this antixenosis for oviposition is associated to the presence of glandular trichomes type IV (Williams et al., 1980; Heinz and Zalom, 1995; Nombela et al., 2000), in addition to its exudates entrap adults (Toscano et al., 2001; Freitas et al., 2002; Muigai et al., 2002; Fancelli et al., 2003, 2008).

Baldin et al. (2005) suggest that PI134417, PI134418 and LA444-1 genotypes presented feeding nonpreference and/or antibiosis, even though in low levels, since they prolong the development period of the whitefly (28.1 to 27.7 days) when compared to the most susceptible genotype, PI126931 (27.2 days). Nevertheless, the development periods of whiteflies obtained by Baldin et al. (2005) were considerably higher to the ones observed in this research - PI134418 (20.3 days), PI134417 (20.9 days), LA444-1 (21.1 days), and PI126931 (22.7 days) - all of them classified as susceptible. The experimental conditions in both experiments were similar (temperature from $25 \pm 2^{\circ} \mathrm{C}$, relative humidity of $70 \pm 10 \%$ and photophase of $13 \mathrm{~h}$ ), which are in within the optimum range for its development, $20-30^{\circ} \mathrm{C}$ (Wang and Tsai, 1996).

Many authors have reported the influence of temperature on the development of $B$. tabaci. In cotton plants, the life cycle of the whitefly ranged from 17 days $\left(30^{\circ} \mathrm{C}\right)$ to approximately 70 days $\left(15^{\circ} \mathrm{C}\right)$ (Butler Jr. et al., 1983; 
Wagner, 1995); in eggplants (Solanum melongena L.), it ranged from 14 days $\left(30^{\circ} \mathrm{C}\right)$ to 105 days $\left(15^{\circ} \mathrm{C}\right)$ (Wang and Tsai, 1996). Temperatures over $35^{\circ} \mathrm{C}$ and extreme air relative humidity were also not favorable to the whitefly development (Avidov, 1957; Gerling et al., 1986; Horowitz, 1986; Wagner, 1995; Wang and Tsai, 1996), giving emphasis to low humidity.

The necessary time for whitefly to complete its development, also depends on its host. Coudriet et al. (1985) observed that the development occurred in a period which was 30\% lower in lettuce (Lactuca sativa L.), cucumber (Cucumis sativus L.), eggplant and pumpkin (Cucurbita maxima Dene.) than in broccoli (Brassica oleracea L.) or carrot (Daucus carota L.). The development period of $B$. argentifolii $(=B$. tabaci B biotype) ranged from 17.3 days on eggplants to 20.9 days on bean (Phaseolus vulgaris L.) (Tsai and Wang, 1996), and was 23 days in poinsettia (Euphorbia pulcherrima Willd. ex Klotzsch) and 25 days in cotton (Bethke et al., 1991). In tomato plants, the development period was 20 days (Hendi et al., 1985; Islan and Shunxiang, 2007). These data were very similar to the ones observed in this experiment; however Islan and Shunxiang (2007) worked in the same conditions as this assay, while for Hendi et al. (1985), the temperature ranged between $30 \pm 2^{\circ} \mathrm{C}$ and the relative humidity was $65 \pm 5 \%$.

Resistant genotypes manifest its adverse effects especially related to insect biology, promoting an increase in the development period; mortality of immatures; mortality before reaching adulthood; size and weight reduction of the individuals; reduction of fecundity; alteration of sexual proportion; and decrease in the longevity of the insect (Painter, 1951; Beck, 1965; Lara, 1991). The development period of insects grown in LA1335, PI365928 and LA722 genotypes took three days longer when compared to the ones grown in PI134418 (20.3 days), on which the development period was shorter. The biggest mortality rates of whitefly nymphs also occurred in PI365928, LA1335 and LA722 genotypes (63.8, 54.5 and $53.3 \%$, respectively) and the smallest in IAC294 and IAC68F-22-2 genotypes (4.9 and 6.2\%, respectively).

It is difficult to determine what kind of resistance mechanism (feeding nonpreference and/or antibioses) is involved on LA1335, PI365928 and LA722 genotypes, since no technique such as electrical penetration graph (EPG) was available which could reveal detailed information about the insect feeding. Nevertheless, it can be inferred that LA1335, PI365928 and LA722 genotypes presented moderate feeding nonpreference and/or antibiosis resistance to $B$. tabaci B biotype.

\section{Acknowledgements}

To Conselho Nacional de Desenvolvimento Científico e Tecnológico (CNPq) and to Fundação de Amparo à Pesquisa do Estado de São Paulo (FAPESP), for research fellowships, and to Dr. Francisco Antônio Monteiro, from the Departament of Soil Science (ESALQ/USP), who provided the nutritive solutions.

\section{References}

Agrianual. 2009. FNP, São Paulo, SP, Brazil. p. 472-478. (in Portuguese).

Amari, K.; Gonzalez-Ibeas, D.; Gómez, P.; Sempere, R.N.; SanchezPina, M.A.; Aranda, M.A.; Diaz-Pendon, J.A.; Navas-Castillo, J.; Moriones, E.; Blanca, J.; Hernandez-Gallardo, M.D.; Anastásio, G. 2008. Tomato torrado virus is transmitted by Bemisia tabaci and infects pepper and eggplant in addition to tomato. Plant Disease 92: 1139.

Avidov, Z. 1957. Bionomics of the tabacco whitefly (Bemisia tabaci Genn.) in Israel. Israel Journal of Agricultural Research 7: 25-41.

Baldin, E.L.L.; Vendramim, J.D.; Lourenção, A.L. 2005. Resistance of tomato genotypes to the whitefly Bemisia tabaci (Gennadius) biotype B (Hemiptera: Aleyrodidae). Neotropical Entomology 34: 435-441. (in Portuguese, with abstract in English).

Beck, S.D. 1965. Resistance of plants to insects. Annual Review of Entomology 10: 207-232.

Bethke, J.A.; Paine, T.D.; Nuessly, G.S. 1991. Comparative biology, morphometrics, and development of two population of Bemisia tabaci (Homoptera, Aleyrodidae) on cotton and poisettia. Annals of the Entomological Society of America 84: 407-411.

Butler Jr., G.D.; Henneberry, T.J.; Clayton, T.E. 1983. Bemisia tabaci (Homoptera, Aleyrodidae): development, oviposition and longevity in relation to temperature. Annals of the Entomological Society of America 76: 310-313.

Channarayappa, S.G.; Muniyappa, V.; Frist, R.H. 1992. Resistance of Lycopersicon species to Bemisia tabaci, a tomato leaf curl virus vetor. Canadian Journal of Botany 70: 2184-2192.

Coudriet, D.L.; Prabhaker, N.; Kishaba, A.N.; Meyerdirk, D.E. 1985. Variation in developmental rate on different hosts and overwintering of the sweetpotato whitefly, Bemisia tabaci (Homoptera, Aleyrodidae). Environmental Entomology 14: 516-519.

De Ilarduya, O.M.; Nombela, G.; Hwang, C.; Williamson, V.M.; Muñiz, M.; Kaloshian, I. 2004. Rme1 is necessary for Mi-1mediated resistance and acts early in the resistance pathway. Molecular Plant-Microbe Interactions 17: 55-61.

Empresa Brasileira de Pesquisa Agropecuária. Centro Nacional de Pesquisas de Hortaliças [EMPRAPA/CNPH]. 2006. Industrial processing tomato cropping. Available at: www.cnph.embrapa.br/paginas/sistemas_producao/ cultivo_tomate_industrializacao.htm. [Accessed Sep. 28, 2009]. (in Portuguese).

Fancelli, M.; Vendramim, J.D. 2002. Development of Bemisia tabaci (Gennadius, 1889) biotype B on Lycopersicon spp. genotypes. Scientia Agricola 59: 665-669.

Fancelli, M.; Vendramim, J.D.; Lourenção, A.L.; Dias, C.T.S. 2003. Attractiveness and oviposition preference of Bemisia tabaci (Gennadius) (Hemiptera: Aleyrodidae) biotype B in tomato genotypes. Neotropical Entomology 32: 319-328. (in Portuguese, with abstract in English).

Fancelli, M.; Vendramim, J.D.; Friguetto, R.T.S.; Lourenção, A.L. 2005. Glandular exudate of tomato genotypes and development of Bemisia tabaci (Genn.) (Sternorryncha: Aleyrodidae) biotype B. Neotropical Entomology 34: 659-665. (in Portuguese, with abstract in English).

Fancelli, M.; Vendramim, J.D.; Lourenção, A.L. 2008. Oviposition and nymphal dispersion of Bemisia tabaci biotype $\mathrm{B}$ on tomato genotypes. Bragantia 67: 933-939. (in Portuguese, with abstract in English).

Freitas, J.A; Nonato, M.F.B.; Souza, V.S.; Maluf, W.R.; Ciociola Jr., A.I.; Leite, G.L.D. 2002. Relationship between acylsugars, glandular trichome and resistance of tomato plants to the silverleaf whitefly. Acta Scientiarum 24: 1313-1316. (in Portuguese, with abstract in English).

García-Cano, E.; Resende, R.O.; Boiteux, L.S.; Giordano, L.B.; Fernández-Muñoz, R.; Moriones, E. 2008. Phenotypic expression, stability, and inheritance of a recessive resistance to monopartite begomoviruses associated with tomato yellow leaf curl disease in tomato. Phytopathology 98: 618-627. 
Gerling, D.; Horowitz, A.R.; Baumgaertner, J. 1986. Autoecology of Bemisia tabaci. Agriculture, Ecosystems \& Environment 17: 5-19.

Heinz, K.M.; Zalom, F.G. 1995. Variation in trichome-based resistance to Bemisia argentifolii (Homoptera, Aleyrodidae) oviposition on tomato. Journal of Economic Entomology 88: 1494-1502.

Hendi, A.; Abdel-Fattah, M.I.; El-Sayed, A. 1985. Biological study on the white-fly, Bemisia tabaci (Genn.) (Homoptera, Aleyrodidae). Bulletin of the Entomological Society of Egypt 65: 101-108.

Horowitz, A.R. 1986. Population dynamics of Bemisia tabaci (Gennadius): with special emphasis on cotton field. Agriculture, Ecosystems \& Environment 17: 37-47.

Islan, M.T.; Shunxiang, R. 2007. Development and reproduction of Bemisia tabaci on three tomato varities. Journal of Entomology 4: 231-236.

Jiang, Y.X.; Nombela, G.; Muñiz, M. 2001. Analysis by DC-EPG of the resistance to Bemisia tabaci on an Mi-tomato line. Entomologia Experimentalis et Applicata 99: 295-302.

Lara, F.M. 1991. Principles of Insect Plant Resistance. 2ed. Ícone, São Paulo, SP, Brazil. p. 31, 52-53. (in Portuguese).

Markham, P.G.; Bedford, I.D.; Liu, S.J.; Pinner, M.S. 1994. The transmission of geminiviruses by Bemisia tabaci. Pesticide Science 42: 123-128.

McAuslane, H.J. 1996. Influence of leaf pubescence on ovipositional preference of Bemisia argentifolii (Homoptera, Aleyrodidae) on soybean. Environmental Entomology 25: 834-841.

Muigai, S.G.; Bassett, M.J.; Schuster, D.J.; Scott, J.W. 2003. Greenhouse and field screening of wild Lycopersicon germplasm for resistance to the whitefly Bemisia argentifolii. Phytoparasitica 31: 1-12.

Muigai, S.G.; Schuster, D.J.; Bassett, M.J.; Scott. J.W.; McAuslane, H.J. 2002. Mechanisms of resistance in Lycopersicon germplasm to the whitefly Bemisia argentifolii. Phytoparasitica 30: 347-360.

Muñiz, M.; Nombela, G. 2001. Differential variation in development of the B- and Q-biotypes of Bemisia tabaci (Homoptera: Aleyrodidae) on sweet pepper at constant temperatures. Environmental Entomology 30: 720-727.

Nombela, G.; Beitia, F.; Muñiz, M. 2000. Variation in tomato host response to Bemisia tabaci (Hemiptera: Aleyrodidae) in relation to acyl sugar content and presence of the nematode and potato aphid resistance gene Mi. Bulletin of Entomological Research 90: 161-167.
Nombela, G.; Beitia, F.; Muñiz, M. 2001. A differential interaction study of Bemisia tabaci Q-biotype on commercial tomato varieties with or without the $M i$ resistance gene, and comparative host responses with the B-biotype. Entomologia Experimentalis et Applicata 98: 339-344.

Nombela, G.; Williamson, V.M.; Muñiz, M. 2003. The root-knot nematode resistance gene $M i-1.2$ of tomato is responsible for resistance against the whitefly Bemisia tabaci. Molecular PlantMicrobe Interactions 16: 645-649

Painter, R.H. 1951. Insect Resistance in Crop Plants. MacMillan, New York, NY, USA. p. 27.

Peralta, I.E.; Knapp, S.; Spooner, D.M. 2006. Nomenclature for wild and cultivated tomatoes. Report of the Tomato Genetics Cooperative 56: 6-12.

Sarruge, J.R. 1975. Nutritive solution. Summa Phytopathologica 1: 231-233. (in Portuguese, with abstract in English).

Tsai, J.H.; Wang, K. 1996. Development and reproduction of Bemisia argentifolii (Homoptera: Aleyrodidae) on five host plants. Environmental Entomology 25: 810-816.

Toscano, L.C.; Boiça Jr., A.L.; Maruyama, W.I. 2002. Nonpreference of whitefly for oviposition in tomato genotypes. Scientia Agricola 59: 677-681.

Verma, A.K.; Ghatak, S.S.; Mukhopadhyay, S. 1990. Effect of temperature on development of whitefly (Bemisia tabaci) (Homoptera, Aleyrodidae) in West Bengal. Indian Journal of Agricultural Sciencies 60: 322-326.

Villas Bôas, G.L. 2005. Integrated management of whitefly. Available at: www.cnph.embrapa.br/paginas/publicacoes/ publicacoes_2005/pdf_vfinal_2005/Comunicado\%20Tec-30.pdf. [Accessed Sep. 30, 2009]. (in Portuguese).

Wang, K.; Tsai, J.H. 1996. Temperature effects on development and reproduction of silverleaf whitefly (Homoptera, Aleyrodidae). Annals of the Entomological Society of America 89: 375-384.

Williams, W.G.; Kennedy, G.G.; Yamamoto, R.T.; Thacker, J.D.; Bordner, J. 1980. 2-Tridecanone: a naturally occurring insecticide from wild tomato, Lycopersicum hirsutum f. glabratum. Science 207: 188-189.

Received September 09, 2009

Accepted May 28, 2010 